\title{
Analysis of the Russian Federation constituent regions' sustainable development goals achievement
}

\author{
Valeriy Smirnov*, Vladislav Semenov, Anna Zakharova, Sergei Zimin, and Natalia \\ Bondarenko \\ Chuvash State University, Moskovsky prospect, 15, 428015 Cheboksary, Russian Federation
}

\begin{abstract}
The article analyzes the Russian Federation constituent regions' sustainable development goals (SDGs) achievement. Identified are the determinant Russian regions, the driving force and the reason for their coherence in achieving sustainable development goals. The study is based on a systematic approach using the method of statistical, neural network and cluster analysis. Results. The study has revealed a contradiction expressed in priority of "SDG 7. Fixed capital investments by areas of investment in terms of "Production of electricity from renewable energy sources, including generated by solar, wind, geothermal power plants, as well as activities to ensure their performance"" line of business and underperformance in terms of "SDG 16. Russia's position in the rating of the World Bank's Doing Business project in terms of the "Getting credit" indicator. The work shows priority in relation to "SDG 3. Life expectancy at birth", which is implemented through national projects. Analysis of the large Russian clusters regional importance identified the Moscow region by "SDG 1. Proportion of the population living below the national poverty line" and "SDG 3. Life expectancy at birth". The analysis of interregional ties revealed determinant regions, the existence of which is supported by the dynamics of the developing Russian market, which is far behind countries with developing economies.
\end{abstract}

\section{Introduction}

The relevance of the analysis of the sustainable development goals achievement of the Russian Federation constituent regions is associated with the acknowledgment by the United Nations (UN) member states of the inadequacy of the measures applied by the world community to ensure the necessary changes. In 2015, the UN 2030 Agenda for Sustainable Development was adopted to end poverty and set the international community on the path to peace, prosperity and opportunity for all on a healthy planet. Achieving the Sustainable Development Goals (SDGs) requires transforming the financial, economic and political systems that govern societies today, in the context with guarantees of the human rights for all.

\footnotetext{
* Corresponding author: walera712006@mail.ru
} 
In order to use the UN potential and maximize the SDGs achievement, it is necessary to analyze the SDGs achievement of the Russian constituent regions. This will allow to define internal reserves and determine areas of cooperation with UN member states in the field of SDGs.

\section{Materials and Methods}

In the modern scientific literature, the opportunities and risks of achieving the varied and diversified SDGs are highlighted. Naoyuki Yoshino, Farhad Taghizadeh-Hesary, Miyu Otsuka revealed that the Covid-19 pandemic and the global economic downturn have led to a loss of interest in renewable energy. This jeopardizes the achievement of the SDGs and the Paris Agreement on climate change [1]. Energy projects aimed at achieving SDG 7 have numerous synergies with other SDGs and their targets [2].

The economy-related goals of SDG 8 (Decent work and economic growth), SDG 9 (Industry, innovation and infrastructure) and SDG 12 (Responsible consumption and production) are close to being met. Acceleration is needed to achieve the goals and targets for education (SDG 4), sustainable cities and communities (SDG 11) and climate action (SDG 13) [3]. Among 17 SDGs dynamics of improvement is shown by SDG 1 (No poverty), SDG 7 (Affordable and clean energy), SDG 11 (Sustainable cities and communities, partnerships). Indicators of education quality under SDG 4 and decent work, economic growth under SDG 8 are declining. Performance was highest in SDG 8, Decent work and economic growth, and lowest in SDG 17, Strengthen the means of implementation and revitalize the global partnership for sustainable development. [4]

Achieving the SDGs will require breakthrough innovation. Diversified enterprises can contribute to achievement of these goals by stimulating innovation, regarding the coevolution of research and innovation with the maturity of innovation ecosystems [5]. The indicator of innovative development is the most complete in terms of coverage and takes market welfare into account [6].

Among the SDGs, significant attention is paid to consumption and production, clean water and sanitation, measures to combat climate change. At the same time, insufficient attention is paid to reducing poverty and inequality, rational use of water resources and sanitation, preservation and sustainable use of the oceans, seas and marine resources [7]. It is necessary to develop the appropriate supporting methodologies that take into account the socio-economic and environmental aspects of water resources management. Policies should target environmental agreements, alternative climate change scenarios, transparent quantitative measures targeting sustainable water demand, as well as evident infrastructure and knowledge transfer channels that can accelerate the implementation of sustainable water resources management at regional and global levels [8]. In the area of sustainable development, it is vital to create environmental awareness among people [9]. The need for investment in sustainable development and social responsibility is increasing as the world faces significant loss of ecosystem and biodiversity functions. [10] Implementation of strategies to achieve SDGs is often obstructed by potential compromise between priorities in the areas of environment protection or human well-being [11].

Focusing on a combination of Circular Economy (CE) and Industry 4.0 (I4.0) practices will contribute to the achievement of the SDGs. CE-I4.0 interconnection directly facilitates the achievement of SDG 7, SDG 8, SDG 9, SDG 11, SDG 12 and SDG 13. CE-I4.0 is crucial in efforts to achieve SDG [12]. Open entrepreneurship has a positive effect on sustainable development [13]. The main factor contributing to the achievement of the SDGs is social entrepreneurship enterprises $[14,15]$.

Networked structures across regions have shown that a one-size-fits-all SDG benchmarking is counterproductive and it is useful to identify a specific community of SDG 
goals and use them as a guide to define priorities for certain goals across regions. [16]. Localization enables governments to effectively adapt sustainable development strategies at a local level [17]. Assessment of space-time progress in achieving the SDGs will help track the global progress [18].

Thus, the world scientific community identifies a set of measures to eradicate poverty and orient the international community towards ensuring peace, prosperity and opportunities for all in the context of effective SDGs adaptation both in a particular country and at the level of certain regions.

\section{Results and Discussion}

Analysis of the growth rates of Russian indicators of sustainable development goals has revealed:

1) low values: negative averages: "SDG 2. Share of households that, when assessing their financial situation, indicated a lack of money for food, \%" and "SDG 16. Russia's position in the rating of the World Bank's Doing Business project in terms of the "Getting credit" indicator; negative medians: "SDG 16. Russia's position in the rating of the World Bank's Doing Business project in terms of the "Getting credit" indicator and "SDG 17. True official development assistance volume (both total and allocated to least developed countries) as a percentage of the gross national income of donor members of the Development Assistance Committee of the Organization for Economic Cooperation and Development (OECD)"; sample variance: "SDG 1. Proportion of the population living below the national poverty line in the year preceding the previous one" and "SDG 15. Area of land plots located within the boundaries of forestries, forest parks, as a percentage of the area of land of all categories“"

2) high values: average and median: "SDG 7. Fixed capital investments by areas of investment by "Production of electricity from renewable energy sources, including generated by solar, wind, geothermal power plants, as well as activities to ensure their performance"" line of business and "SDG 16. Proportion of the population using the Internet to receive state and municipal services, as a percentage of the total population, $\%$ of the total population aged 15-72"; sample variance: "SDG 7. Fixed capital investments by areas of investment by "Production of electricity from renewable energy sources, including generated by solar, wind, geothermal power plants, as well as activities to ensure their performance"" line of business and "SDG 15. Area of reclaimed land per year".

Large clusters were identified as a result of the Russian indicators of sustainable development goals growth rates cluster analysis: "SDG 1. Proportion of the population living below the national poverty line in the year preceding the previous one"; "SDG 1. Real incomes of people, as a percentage of the previous period"; "SDG 3. Life expectancy at birth". The tightest cohesiveness is found with: "SDG 3. Life expectancy at birth" and "SDG 9. Share of researchers under the age of 39 in the total number of Russian researchers", "SDG 9. Share of households with Internet access in the total number of households", "SDG 9. Hard surface public roads density per 1000 sq. km of territory, km per 1000 sq. km of territory", "SDG 8. Labor productivity index, \% of the previous year", "SDG 4. Proportion of youth with information and communication technology skills, \% of the total population aged 15-24", "SDG 4. Proportion of adults with information and communication technology skills, \% of the total population aged 15-74, (15-72 before 2017)".

Neural network analysis of the large Russian clusters regional importance identified the highest average importance of "SDG 3. Life expectancy at birth, years" in which the following constituent regions stand out: St. Petersburg, Arkhangelsk region, Kemerovo region, Moscow region, Republic of Karelia and Perm Territory. By "SDG 1. Proportion of 
the population living below the national poverty line for the year preceding the previous one, \%" the Republic of Ingushetia, Moscow Region, the Chechen Republic, Republic of Khakassia, Republic of Mordovia and Karachay-Cherkess Republic stand out. By "SDG 1. Real incomes of the people, as a percentage of the previous period, \%" the Vologda Region, Kursk Region, Smolensk Region, Republic of Dagestan, Voronezh Region and Zabaikalye Territory stand out.

Analysis of interregional cohesions (clusters) in achievement of Russian Sustainable Development Goals found determinant regions which are Bryansk Region, Republic of Altai, Komi Republic, Rostov Region, Stavropol Territory and the Khanty-Mansi Autonomous District - Yugra.

The analysis of the Sustainable Development Goals achievement by the Russian Federation constituent regions identified the determinant territories that are the KhantyMansi Autonomous District - Yugra and the Komi Republic.

\section{Conclusion}

The analysis of the Sustainable Development Goals achievement by the Russian Federation constituent regions revealed the Russian SDGs achievement driving force, which is associated with an increase in proportion of population using the Internet network to get state and municipal services caused by low cost of unlimited Internet (5-6 times less than the world average) as well as cost of 1 GB mobile data and four times lower electricity cost in comparison to the European Union.

Low electricity cost fits "SDG 7. Fixed capital investments by areas of investment by "Production of electricity from renewable energy sources, including generated by solar, wind, geothermal power plants, as well as activities to ensure their performance"" line of business. At the same time, the priority use of the Internet by the population to get state and municipal services in the total volume of Internet services significantly limits the achievement of "SDG 16. Promote peaceful and inclusive societies for sustainable development, provide access to justice for all and build effective, accountable and inclusive institutions at all levels."

For the Russian reality, it is advisable to cluster the determinant territories according to the priority of "SDG 3. Ensure healthy lives and promote well-being for all at all ages", the foundation of which is laid in the national projects "Science", "Education", "Digital Economy", "Labor Productivity", "Safe and High-Quality Highways". In this context ("SDG 3. Ensure healthy lives and promote well-being for all at all ages" and "SDG 1. End poverty in all its forms everywhere") the Moscow Region, Bryansk Region, Republic of Altai, Komi Republic, Rostov Region, Stavropol Territory and the Khanty-Mansi Autonomous District - Yugra stand out.

\section{References}

1. N. Yoshino, F. Taghizadeh-Hesary, M. Otsuka, Finance Research Letters, 38, 101695 (2021)

2. J. Castor, K. Bacha, F. F. Nerini, Energy Research \& Social Science, 68, 101556 (2020)

3. G. Halkos, E.-C. Gkampoura, Economic Analysis and Policy, 70, 94 (2021)

4. S. Lamichhane, G. Eğilmez, R. Gedik, M.K.S. Bhutta, B. Erenay, Journal of Cleaner Production, 287, 125040 (2021) 
5. P.A. Nylund, A. Brem, N. Agarwal, Journal of Cleaner Production, 281, 125329 (2021)

6. D. Cook, B. Davíðsdóttir, Ecological Economics, 184, 106996 (2021)

7. Y.-J. Cai, T.-M. Choi, Transportation Research Part E: Logistics and Transportation Review, 141, 102010 (2020)

8. S. Tsani, P. Koundouri, E. Akinsete, Environmental Science \& Policy, 114, 570 (2020).

9. T. Czvetko, G. Honti, V. Sebestyen, J. Abonyi, Heliyon, 7(2), e06174 (2021)

10. K. Winans, F. Dlott, E. Harris, J. Dlott, Journal of Cleaner Production, 291, 125797 (2021)

11. S. Yang, W. Zhao, Y. Liu, F. Cherubini, B. Fu, P. Pereira, Geography and Sustainability, 1(4), 321 (2020)

12. T.E.T. Dantas, E.D. Souza, I.R. Destro, G. Hammes, C.M.T. Rodriguez, S.R. Soares, Sustainable Production and Consumption, 26, 213 (2021)

13. S. Dhahri, S. Slimani, A. Omri, Technological Forecasting and Social Change, 165, $120561(2021)$

14. F. Günzel-Jensen, N. Siebold, A. Kroeger, S. Korsgaard, Journal of Business Venturing Insights, 13, e00162 (2020)

15. T. Yamane, S. Kaneko, Journal of Cleaner Production, 285, 125291 (2021)

16. R.B. Swain, S. Ranganathan, World Development, 138, 105136 (2021)

17. S. ElMassah, M. Mohieldin, Ecological Economics, 169, 106490 (2020)

18. Y. Huan, T. Liang, H. Li, C. Zhang, Science of The Total Environment, 752, 141875 (2021)

19. V. V. Smirnov, V. L. Semenov, E. N. Kadyshev, T. V. Talanova, A. N. Zakharova, N. G. Gubanova, Proceedings of the 35th International Business Information Management Association Conference (IBIMA). Education Excellence and Innovation Management: A 2025 Vision to Sustain Economic Development during Global Challenges, 3736 (2020)

20. V. V. Smirnov, V. L. Semenov, O. L. Taranova, T. V. Talanova, A. N. Zakharova, N. A. Ivanova, Proceedings of the 35th International Business Information Management Association Conference (IBIMA). Education Excellence and Innovation Management: A 2025 Vision to Sustain Economic Development during Global Challenges, 3731 (2020)

21. V. V. Smirnov, A. N. Zakharova, T. V. Talanova, A. G. Abramova, S. A. Petunova, I. B. Getskina, M. N. Yaklashkin, Proceedings of the 35th International Business Information Management Association Conference (IBIMA). Education Excellence and Innovation Management: A 2025 Vision to Sustain Economic Development during Global Challenges, 7741 (2020) 